\title{
Immunohistochemistry of great scallop Pecten maximus larvae experimentally challenged with pathogenic bacteria
}

\author{
Nina Sandlund ${ }^{1, *}$, Lise Torkildsen ${ }^{1}$, Thorolf Magnesen ${ }^{2}$, Stein Mortensen ${ }^{1}$, \\ Øivind Bergh ${ }^{1}$
}

\author{
${ }^{1}$ Institute of Marine Research, PO Box 1870 Nordnes, 5817 Bergen, Norway \\ ${ }^{2}$ Centre for Studies of Environment and Resources, University of Bergen, PO Box 7800, 5020 Bergen, Norway
}

\begin{abstract}
Three challenge experiments were carried out on larvae of the great scallop Pecten maximus. Larvae were bath-challenged with Vibrio pectenicida and 5 strains resembling Vibrio splendidus and one Pseudoalteromonas sp. Unchallenged larvae were used as negative controls. The challenge protocol was based on the use of a multidish system, where the scallop larvae $(10,13$ and $15 \mathrm{~d}$ post-hatching in the 3 experiments, respectively) were distributed to $2 \mathrm{ml}$ wells with stagnant seawater and exposed to the bacterial cultures by bath challenge. Presence of the challenge bacteria in the wells was verified by polymerase chain reaction (PCR). A significantly increased mortality was found between 24 and $48 \mathrm{~h}$ in most groups challenged with $V$. pectenicida or $V$. splendiduslike strains. The exception was found in larval groups challenged with a Pseudoalteromonas sp. LT 13, in which the mortality rate fell in 2 of the 3 challenge experiments. Larvae from the challenge experiments were studied by immunohistochemistry protocol. Examinations of larval groups challenged with $V$. pectenicida revealed no bacterial cells, despite a high degree of positive immunostaining. In contrast, intact bacterial cells were found in larvae challenged with $V$. splendidus. In the case of larvae challenged with the Pseudoalteromonas sp., positive immuno-staining was limited to visible bacteria inside the digestive area and cells of the mucosa. The experiments confirm that $V$. splendidus and V. pectenicida are pathogenic to scallop larvae, and that the Pseudoalteromonas strain is probably not a primary pathogen, although it cannot be ruled out as a secondary pathogen.
\end{abstract}

KEY WORDS: Pecten maximus · Vibrio splendidus · Immunohistochemistry · Challenge experiments · Larvae Resale or republication not permitted without written consent of the publisher

\section{INTRODUCTION}

The great scallop Pecten maximus L occurs naturally along the coasts of Europe, north to the Lofoten islands in Norway. Due to good prices on the European market, suitable environmental conditions and a harvestable wild population, potential for commercial scallop production in Norway has been identified, and attempts to cultivate the species are currently underway in Norway and France (reviewed by Bergh \& Strand 2001).

Aquaculture of the great scallop in Norway is based upon hatchery-produced spat. This production is commonly associated with highly variable survival during the larval stages. Mortalities of up to $100 \%$ during the early life stages have frequently been experienced at the only Norwegian hatchery, and the total annual production of $2 \mathrm{~mm}$ spat has been limited to about 2 million since 1996 (Torkildsen \& Magnesen 2004).

Opportunistic bacteria are probably the primary cause of the mortalities (Nicolas et al. 1996, Robert et al. 1996, Torkildsen et al. 2000, 2002, 2005). This is a well-known problem in bivalve hatcheries, and several bacteria, especially Vibrio species, cause diseases in bivalves. Vibrio pectenicida has been isolated from moribund Pecten maximus larvae in French hatcheries (Lambert et al. 1998). In cultivated northern Chilean scallop Argopecten purpuratus, vibriosis caused by 
$V$. anguillarum (Riquelme et al. 1995) and V. alginolyticus (see Riquelme et al. 1996a,b) has caused high mortality. $V$. splendidus was the causative agent of annual summer mortalities of the Pacific oyster Crassostrea gigas in France (Lacoste et al. 2001, Le Roux et al. 2002, Waechter et al. 2002). The causative agent of brown ring disease (BRD), $V$. tapetis (Borrego et al. 1996) caused high mortalities in Manila clams Ruditapes philippinarum, especially in France. Mortalities up to $100 \%$ caused by $V$. tapetis occurred in a challenge study of Manila clams (Allam et al. 2002). Other bacterial species causing disease in bivalves are Aeromonas hydrophila (Riquelme et al. 1996a), Chlamydia (Leibovitz 1989), Chlamydia-like organisms (Morrison \& Shum 1982, Renault \& Cochennec 1995, Hine \& Diggles 2002) and Rickettsia-like organisms (Elston 1986, Le Gall et al. 1988, 1991, Wu \& Pan 1999).

However, bacteria are also a part of the diet of bivalves, which feed on microalgae, other microplankton, bacteria and particulate organic material (Hovgaard et al. 2001). When Samain et al. (1987) studied water quality, they found that feed particle sizes between 0.22 and $1 \mu \mathrm{m}$ significantly improved the growth of Pecten maximus larvae and suggested that bacteria are an important part of the food supply. Comparable results were found in studies of the Chilean scallop Argopecten purpuratus. Larval growth and survival increased when this species was cultivated in water filtered though a $5 \mu \mathrm{m}$ filter, compared with filtration though a $0.22 \mu \mathrm{m}$ filter (Riquelme et al. 1997). In hatcheries, scallop larvae are normally fed various species of algae, typically Pavlova lutheri, Isochrysis galbana, Skeletonema costatum, Chaetoceros calcitrans and Tetraselmis suecica, in different combinations and concentrations (Ruiz-Ponte et al. 1999, Riquelme et al. 2001, Torkildsen \& Magnesen 2004). The different algal cultures and the scallop larvae are associated with different bacterial communities (Sandaa et al. 2003). The use of bacterial supplements, as an addition to algal diets, was suggested by Douillet \& Langdon (1993) and Douillet (1993a,b). By using ${ }^{14} \mathrm{C}$-labelled live or heat-killed bacteria, Douillet (1993a,b) demonstrated that Pacific oyster, Crassostrea gigas, larvae can digest and assimilate bacterial carbon. Crosby et al. (1990) found similar abilities in the American oyster $C$. virginica. In early studies of the blue mussel Mytilus edulis, Birkbeck \& McHenery (1982) concluded that mussels are capable of selecting lysozyme-sensitive bacteria for subsequent processing. Douillet \& Langdon (1993) demonstrated that the addition of a particular bacterial strain, CA2, possibly an Alteromonas sp., enhanced the growth and survival of Pacific oyster larvae. The optimal bacterial concentra-

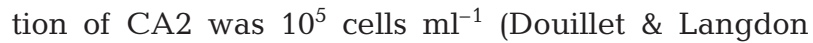

1994). $P$. maximus larvae showed significantly lower mortality rates when cell extracts of Roseobacter strain BS107, were added to larval cultures (Ruiz-Pointe et al. 1999).

Since the literature cited above clearly documents that bacteria in bivalve cultures may represent both threats and valuable food components, it is important to describe the action of different bacteria found in larval cultures. An understanding of the processes involved in larval mortality is essential. The aim of the present study was to investigate the action of bacteria suspected of being pathogenic to scallop larvae. Larval groups were challenged with bacterial isolates from Pecten maximus larvae, resembling Vibrio splendidus and Pseudoalteromonas (Torkildsen 2004). Mortality was compared to that of larvae challenged with the known pathogenic bacterium $V$. pectenicida (Lambert et al. 1998) and an unchallenged control group. Immunohistochemistry was employed to assess uptake of the bacteria and their effect on larval tissues.

\section{MATERIALS AND METHODS}

Broodstock, oocytes and larvae. Scallop larvae were produced according to standard cultivation procedures at the scallop hatchery Scalpro A/S, Rong, near Bergen, as described by Torkildsen \& Magnesen (2004). Broodstock originated from the County of Hordaland in western Norway $\left(60^{\circ} \mathrm{N}\right)$. Oocytes were collected and hatched at the hatchery in April 2001. Spawning was induced by thermal shock, and the oocytes were fertilised as described by Gruffydd \& Beaumont (1970). Larvae were kept in 8001 tanks with stagnant seawater at $18 \pm 1^{\circ} \mathrm{C}$ taken from the nearby fjord at a depth of $60 \mathrm{~m}$. The water was filtered through a $1 \mu \mathrm{m}$ filter bag and renewed 3 times a week. Larvae were fed a diet consisting of mixed monocultures of the algae Isochrysis galbana (Parke) Tahitian strain, Pavlova lutheri (Droop), Chaetoceros calcitrans (Takano)/ C. mulleri, Skeletonema costatum and Tetraselmis suecica at a ratio of 3:2:3:1:1 with a total concentration of 50 cells $\mu \mathrm{l}^{-1}$.

Bacteria. The following bacteria were selected for challenge experiments: LT 06, LT 13, LT 21 and LT 73, isolated by Torkildsen et al. $(2000,2002,2005)$ and PMV 18 and PMV 19 (C. Lambert unpubl.). LT 13 belongs to the genus Pseudoalteromonas, while the others (PMV 18, PMV 19, LT 06, LT 21 and LT 73) resemble Vibrio splendidus (Torkildsen et al. 2005). Challenge experiments included a negative control (unchallenged control) and a positive control challenged with $V$. pectenicida strain A496, a known pathogen of great scallop larvae (Lambert et al. 1998), referred to as challenged control. All bacteria were 
stored at $-80^{\circ} \mathrm{C}$ in a $20 \%$ glycerol/marine broth (Difco 2216) stock. They were incubated at $18^{\circ} \mathrm{C}$ and grown on petri dishes with Difco 2216 marine agar (MA) for $48 \mathrm{~h}$. Colonies of the bacteria were transferred to Erlenmeyer flasks with $50 \mathrm{ml}$ of marine broth (MB) (Difco 2216) and shaken at $90 \mathrm{rpm}$ in a shaking incubator (INFORS AG) for $48 \mathrm{~h}$. PMV 18 grows slower than the other strains and was therefore grown for $72 \mathrm{~h}$. Bacteria were harvested by centrifugation (Heraeus Sepathec Megafuge $1.0 \mathrm{R}$ ) at $2772 \times g$ for $10 \mathrm{~min}$ at $4^{\circ} \mathrm{C}$, washed twice in phosphate-buffered saline (PBS) and resuspended in PBS. The number of live cells in the suspensions was determined by counting colony-forming units (CFU). Each bacterial suspension $(100 \mu \mathrm{l})$ was plated on MA and grown for $48 \mathrm{~h}$. Colonies were then counted, and total cell concentration was determined (Table 1). For each experiment, 2 parallel counts were made.

Challenge experiments. Three almost identical challenge experiments were performed. Scallop larvae were exposed to bacteria at different ages post hatching, $10 \mathrm{~d}$ in challenge Expt I, $13 \mathrm{~d}$ in Expt II and $15 \mathrm{~d}$ in Expt III. The multidish tray containing the control group of Expt I was lost during handling, and thus this experiment did not include a negative control. Larvae were transferred to 24 -well polystyrene multidishes (Nunc) with $2 \mathrm{ml}$ of sterile seawater (SSW) (28 ppt

Table 1. Cell concentration (cells $\mathrm{ml}^{-1}$ )in all bacterial suspensions for each experiment, based on viability counts. CFU = colony-forming units on plates 1 and 2. $100 \mu \mathrm{l}$ was added to each plate. A496 = Vibrio pectenicida. The bacterial strains PMV18, PMV 19, LT 06, LT 21 and LT 73 resemble Vibrio splendidus, while LT 13 resembles Pseudoalteromonas

\begin{tabular}{|lccccc|}
\hline \multirow{2}{*}{ Bacteria } & Expt & Dilution & \multicolumn{2}{c|}{ CFU } & Cell \\
& & plated & Plate 1 & Plate 2 & conc. \\
\hline A496 & I & $1.00 \times 10^{7}$ & 3 & 3 & $3.00 \times 10^{8}$ \\
PMV 18 & I & $1.00 \times 10^{6}$ & 9 & 7 & $8.00 \times 10^{7}$ \\
PMV 19 & I & $1.00 \times 10^{7}$ & 1 & 4 & $2.50 \times 10^{8}$ \\
LT 06 & I & $1.00 \times 10^{7}$ & 3 & 3 & $3.00 \times 10^{8}$ \\
LT 13 & I & $1.00 \times 10^{7}$ & 4 & 6 & $5.00 \times 10^{8}$ \\
LT 21 & I & $1.00 \times 10^{7}$ & 4 & 2 & $3.00 \times 10^{8}$ \\
LT 73 & I & $1.00 \times 10^{7}$ & 3 & 3 & $3.00 \times 10^{8}$ \\
A496 & II & $1.00 \times 10^{6}$ & 3 & 5 & $4.00 \times 10^{7}$ \\
PMV 18 & II & $1.00 \times 10^{7}$ & 1 & 3 & $2.00 \times 10^{8}$ \\
PMV 19 & II & $1.00 \times 10^{7}$ & 3 & 6 & $4.50 \times 10^{8}$ \\
LT 06 & II & $1.00 \times 10^{7}$ & 3 & 4 & $3.50 \times 10^{8}$ \\
LT 13 & II & $1.00 \times 10^{7}$ & 5 & 7 & $6.00 \times 10^{8}$ \\
LT 21 & II & $1.00 \times 10^{7}$ & 5 & 6 & $5.50 \times 10^{8}$ \\
LT 73 & II & $1.00 \times 10^{7}$ & 4 & 4 & $4.00 \times 10^{8}$ \\
A496 & III & $1.00 \times 10^{6}$ & 6 & 5 & $5.50 \times 10^{8}$ \\
PMV 18 & III & $1.00 \times 10^{7}$ & 4 & 6 & $5.00 \times 10^{7}$ \\
PMV 19 & III & $1.00 \times 10^{7}$ & 9 & 8 & $8.50 \times 10^{8}$ \\
LT 06 & III & $1.00 \times 10^{7}$ & 8 & 9 & $8.50 \times 10^{8}$ \\
LT 13 & III & $1.00 \times 10^{7}$ & 7 & 6 & $8.50 \times 10^{8}$ \\
LT 21 & III & $1.00 \times 10^{7}$ & 5 & 5 & $5.00 \times 10^{8}$ \\
LT 73 & III & $1.00 \times 10^{7}$ & 9 & 8 & $8.50 \times 10^{8}$ \\
& & & & & \\
\hline
\end{tabular}

salinity), with about 20 to 40 larvae in each well. Ideally, the number of larvae per well should have been identical, but priority was given to minimizing handling. Given the small size (100 to $150 \mu \mathrm{m}$ ) and fragility of the larvae, an approximately equal number of larvae per well combined with a large number of replicates was considered preferable to the risk of losing larvae due to physical handling. To each well (except for the unchallenged control) $100 \mu \mathrm{l}$ of the abovementioned $48 \mathrm{~h}$ bacterial suspension (PBS+bacteria) was added. The cell concentrations of the bacterial suspensions were approximately $10^{8} \mathrm{cells} \mathrm{ml}^{-1}$, except for 3 suspensions that had a cell concentration of $10^{7}$ cells $\mathrm{ml}^{-1}$ (Table 1). One multidish (i.e. 24 wells) was used for each bacterial strain. Inoculations were repeated with 10 -fold and 100 -fold dilutions of the bacterial culture. The larvae were incubated at $16^{\circ} \mathrm{C}$ in an air-conditioned room. Live and dead larvae were counted after 24 and $48 \mathrm{~h}$ using an inverted stereoscopic microscope (Leitz DM IL). Six wells were counted for each dilution and bacterial strain. Nonswimming larvae and larvae lying passively on the bottom were counted as dead. In some wells it was difficult to determine the exact number of live and dead larvae, especially when they were swimming rapidly. To reduce the possibility of error, the wells were counted twice. At the end of each counting session, 12 wells were emptied with a pipette, and larvae were fixed in $4 \%$ phosphate-buffered formaldehyde for further processing for immunohistochemistry. This procedure did not discriminate among live, moribund and dead larvae. The 12 wells that were emptied included the 6 counted wells.

For bacterial samples, $100 \mu \mathrm{l}$ water was taken from randomly selected wells from each group, and plated on MA. The remaining larvae were returned to the air-conditioned room. The counting procedure lasted about 15 min. Bacterial colonies grown from the wells were inoculated in Erlenmeyer flasks with $50 \mathrm{ml} \mathrm{MB}$, incubated at $18^{\circ} \mathrm{C}$ and shaken at $90 \mathrm{rpm}$ for $48 \mathrm{~h}$. The cultures were frozen at $-80^{\circ} \mathrm{C}$ in $20 \%$ glycerol until the polymerase chain reaction (PCR) was performed. Three counts were made for each experiment.

Statistical considerations. The survival/mortality data were not normally distributed; nonparametric tests were used for statistical analyses. Testing for several proportions ( $\alpha=0.025$, critical region: $\chi^{2}<12.832$ for $v=5 \mathrm{df}$ ) (Walpole et al. 2002) was performed to test the homogeneity among the 6 wells that were counted for each larval group, after 24 and 48 h. A $2 \times 2$ contingency table $(\mathrm{p}<0.05, \mathrm{df}=1)$, performed 
in Statistica v 5.0 (StatSoft), was used to test for mortality differences between the 2 control larval groups and the challenged test larval groups.

Polymerase chain reaction (PCR), DNA amplification. This method was used to verify that the bacteria present in the wells actually were LT 06 and LT 13. Specific primers were used for LT 06 f1: 55-82 (ACAGTAACAATCCTTCGGGTGCG), r1: 452-476 (TCAAGAGGCGCCGCTATTAACTAC) and LT 13 f1: 55-80 (AACAGAAAGTAGCTTGCTACTTGGC), r1: 435-460 (TCACAGCTAGCAGGTATTAACTACT). The fragment size produced by the LT 06 primers is $417 \mathrm{bp}$ and the fragment produced by the LT 13 primers is $405 \mathrm{bp}$. The PCR was performed in reaction mixtures of $25 \mu \mathrm{l}$ in $0.2 \mathrm{ml}$ 8-strip PCR tubes (Axygen). The mixture contained $14.85 \mu \mathrm{l}$ of distilled water, $3 \mu \mathrm{l}$ of $\mathrm{MgCl}_{2}, 2.5 \mu \mathrm{l}$ of PCR buffer, $2.5 \mu \mathrm{l}$ of $1.25 \mathrm{mM}$ dNTP (Promega Madison), $0.5 \mu l$ of each primer, $0.15 \mu \mathrm{l}$ of Taq polymerase (Promega) and $1 \mu \mathrm{l}$ of bacterial sample. The mixture without bacterial sample was used as a negative control, and LT 06 and LT 13 were used as positive controls. Reactions were carried out in a Gene Amp, PCR systems 9700 (Perkin Elmer) with an initial denaturation step of $94^{\circ} \mathrm{C}$ for $2 \mathrm{~min}, 35$ cycles of denaturation $\left(94^{\circ} \mathrm{C}\right.$ for $\left.1 \mathrm{~min}\right)$, annealing $\left(62^{\circ} \mathrm{C}\right.$ for $30 \mathrm{~s})$, extension $\left(72^{\circ} \mathrm{C}\right.$ for $\left.1 \mathrm{~min}\right)$ and final extension at $72^{\circ} \mathrm{C}$ for $5 \mathrm{~min}$. Amplified DNA, $5 \mu \mathrm{l}$, was examined by horizontal 1\% agarose (SeaKem LE). Gene Mass Ruler DNA ladder mix (MBI Ferments), $2 \mu \mathrm{l}$, was used as a nucleic acid standard. Visualisation was obtained by UV illumination after staining with ethidium bromide.

Immunohistochemistry. All microscope slides used for testing the different bacteria against the antiserum were coated with a diluted Poly-L-Lysine solution (Sigma Diagnostics). Coating was carried out to allow the bacteria to attach to the slides during the staining procedure.

Antisera were made for the bacterial strains Vibrio pectenicida (anti-A496), LT 06 (anti-LT 06) and LT 13 (anti-LT 13) and were produced according to the method of Oeding (1957). Formaldehyde-killed, washed bacteria were administered by intravenous injection to the rabbits. The polyclonal rabbit antisera were absorbed by the method of Knappskog et al. (1993), to minimize the possibility of cross-reaction. Each absorbed antiserum (anti-A496, anti-LT 06 and antiLT 13) was tested for cross-reaction with bacterial strains and larval tissue samples prior to the immunohistochemistry. The dilution used on tissue samples of each antiserum was determined by testing a range of antiserum dilutions on bacterial samples.

Larval samples fixed in $4 \%$ phosphate-buffered formaldehyde were dehydrated in ethanol and embedded in paraffin. Larvae were sectioned at $3 \mu \mathrm{m}$ (Leica Jung Biocut 2035), incubated at $58^{\circ} \mathrm{C}$ for $30 \mathrm{~min}$, dewaxed in xylene, rehydrated in a series of ethanol baths and washed in running water. The absorbed polyclonal rabbit antisera, anti-A496, anti-LT 06 and anti-LT 13, were diluted 1:10 in Tris-buffered saline (TBS) with $2.5 \%$ bovine serum albumin (BSA). To prevent non-specific antibody binding, sections were blocked by using $5 \%$ BSA in Tris-buffered formaldehyde for $20 \mathrm{~min}$. Avidine-biotin-alkaline phosphatase complex (ABC/AP) reaction kit (DAKO A/S) and New Fuchsin Substrate system (Dako) were used to visualise positive staining. Shandon's haematoxylin was used for counterstaining. At each stage of staining, 2 controls were used. Unchallenged larvae were used as negative controls and bacterial smears on microscope slides were used as positive controls. The same procedure was used to stain both larvae and bacteria. During the staining procedure, tissue sections and bacterial samples were kept separately in order to prevent cross-contamination. To ensure complete staining of all the larvae, each microscope slide was totally covered with the immunohistochemistry kit. All incubations were performed at room temperature $\left(20^{\circ} \mathrm{C}\right)$ in a humidity chamber. A Leica DMBE microscope equipped with a Leica Wild MPS52 phototube was used to photograph the sections. Films used were Fujichrome 100 and Fujichrome 200.

\section{RESULTS}

\section{Challenge experiments}

Survival and mortality data were pooled if there were no significant differences among the 6 wells. From these results, 8 out of 46 of the chi-square statistical analyses rejected the $\mathrm{H}_{\mathrm{o}}$ hypothesis, i.e. rejected that all populations had equal survival rates. We concluded that there were differences in mortality among the 6 wells (Tables $2 \& 3$ ).

In most challenged larval groups, mortality (i.e number of non-motile larvae) was higher at 48 than at $24 \mathrm{~h}$ after challenge (Table 3 ). The exception was larval groups challenged with LT 13, in which the mortality rate decreased in Expts II and III. In the unchallenged control group, there was no difference between 24 and $48 \mathrm{~h}$ (Table 3). Mortality within the unchallenged control larval groups was higher in Expt III than in Expt II.

Mortality in the unchallenged control larval groups was between 18.2 and $31.4 \%$ (average mortality was approximately $25 \%$ ) (Table 3 ). In challenged control larval groups (larvae challenged with Vibrio pectenicida) the mortality rate varied between $17.6 \%$ and $65.7 \%$ (average mortality $37 \%$ ) (Table 3 ). The difference in mortality rates between the 2 control groups was only significant in Expt III after $24 \mathrm{~h}(2 \times 2$ contin- 
Table 2. Treatments found to be significantly different in mortality. The bacterial strains LT 21, LT 73 and PMV 19 resemble Vibrio splendidus, while LT 13 resembles Pseudoalteromonas

\begin{tabular}{|lclc|}
\hline Expt & Time $(\mathrm{h})$ & Bacteria & $\chi^{2}$ \\
\hline I & 24 & LT 72 & 14.87 \\
I & 48 & LT13 & 16.43 \\
I & 48 & LT21 & 13.87 \\
II & 24 & LT73 & 15.75 \\
II & 48 & PMV 19 & 14.71 \\
III & 24 & LT2 21 & 14.85 \\
III & 48 & PMV 19 & 11.25 \\
III & 48 & LT21 & 20.64 \\
\hline
\end{tabular}

gency table, $\mathrm{p}=0.0162$ ). At that time, mortality rates in all challenged groups were significantly different from the unchallenged control larval group (Table 3).

Larvae challenged with LT 06 suffered an average mortality rate of approximately $40 \%$, ranging between 28.6 and $64.7 \%$ (Table 3). Mortality in these groups was significantly different from the mortality in the unchallenged control larval groups in Expt III after $24 \mathrm{~h}$ $(2 \times 2$ contingency table, $\mathrm{p}=0.0110)$. When compared with mortality in the challenged control larval groups, a significant difference in mortality was found in Expt I after $24 \mathrm{~h}$ of challenge $(2 \times 2$ contingency table, $\mathrm{p}=$ 0.0051).

In general, the challenge with LT 13 resulted in low mortality in most larval groups and the average percentage mortality was lowest of all challenged groups (approximately 29\%). Mortality in these larval groups was the same as or less than in the unchallenged control groups (Table 3), and was significantly different only in the Expt III after $24 \mathrm{~h}(2 \times 2$ contingency table, $\mathrm{p}=0.0286$ ). Mortality in larval groups challenged with LT 13 was significantly different from the challenged control larval groups in Expts II and III, $48 \mathrm{~h}$ post- challenge $(2 \times 2$ contingency table, $\mathrm{p}=0.0019$ and $\mathrm{p}=$ 0.0258 , respectively)

Challenge with LT 21 caused an average mortality rate of approximately $45 \%$ (Table 3 ), and mortality was significantly different from that in the unchallenged controls in Expt II, 24 and $48 \mathrm{~h}$ after the challenge $(2 \times 2$ contingency table, $\mathrm{p}=0.0294$ and $\mathrm{p}=0.0000$, respectively) and Expt III after 24 and $48 \mathrm{~h}(2 \times 2$ contingency table $\mathrm{p}=0.0010$ and $\mathrm{p}=0.0000$ ). In comparison with the challenged control larval groups, the difference in mortality was significant in Expt I, 24 h post challenge $(2 \times 2$ contingency table, $p=0.0002)$ and in Expt II and III after $48 \mathrm{~h}$ of challenge $(2 \times 2$ contingency table, $\mathrm{p}=$ 0.0126 and $p=0.0026$, respectively).

Challenge with the bacterial strain LT 73 resulted in high mortality in all challenge experiments, especially in Expt III after $48 \mathrm{~h}$ of challenge (86.4\%) (Table 3). Average mortality was approximately $49 \%$, which was the highest of all groups. The mortality was significantly different from that in the unchallenged control larvae in Expt II after both 24 and 48 h $(2 \times 2$ contingency table, $p=0.0349$ and $p=0.0000$, respectively), and in Expt III after 24 and $48 \mathrm{~h}$ of challenge $(2 \times 2$ contingency table, $p=0.0127$ and $p=0.0000$, respectively). When compared to the mortality experienced in the challenged control larval groups, significant differences were found in Expts I and III after $24 \mathrm{~h}(2 \times 2 \mathrm{con}$ tingency table, $\mathrm{p}=0.0000$ and $\mathrm{p}=0.0162$, respectively).

PMV 18 caused an average mortality of approximately $38 \%$ (Table 3). Mortality in larval groups challenged with PMV 18 and the unchallenged control larval groups was significantly different in Expts II and III after $24 \mathrm{~h}(2 \times 2$ contingency table, $\mathrm{p}=0.0000$ and $\mathrm{p}=$ 0.0001 , respectively). Compared with the challenge control larval groups, the mortality in larval groups challenged with PMV 18 was significantly different in Expt I at both 24 and $48 \mathrm{~h}(2 \times 2$ contingency table, $\mathrm{p}=$ 0.0245 and $p=0.0009$ ) and in Expt II after 24 and $48 \mathrm{~h}$

Table 3. Percent mortality of challenge Expts I, II and III including unchallenged and challenged control groups. Challenged control: larval groups challenged with Vibrio pectenicida. ND: no data (Challenge Expt I did not include an unchallenged control group). ${ }^{*}$ Significantly different from the unchallenged control larval groups $(\mathrm{p}<0.05) .{ }^{\wedge}$ Significantly different from the challenged control larval groups $(\mathrm{p}<0.05)$. The bacterial strains PMV18, PMV 19, LT 06, LT 21 and LT 73 resemble Vibrio splendidus, while LT 13 resembles Pseudoalteromonas

\begin{tabular}{|c|c|c|c|c|c|c|c|c|c|}
\hline Expt & $\begin{array}{l}\text { Time } \\
(\mathrm{h})\end{array}$ & $\begin{array}{c}\text { Unchallenged } \\
\text { control }\end{array}$ & $\begin{array}{l}\text { Challenged } \\
\text { control }\end{array}$ & PMV 18 & PMV19 & LT 06 & LT 13 & LT 21 & LT 73 \\
\hline I & 24 & ND & 17.6 & $29.4^{\wedge}$ & $36.8^{\wedge}$ & $31.5^{\wedge}$ & 26.3 & $33.3^{\wedge}$ & $36.5^{\wedge}$ \\
\hline I & 48 & ND & 65.7 & $40.7^{\wedge}$ & 75.0 & 64.7 & 50.5 & 65.9 & 53.0 \\
\hline II & 24 & 18.2 & 24.1 & $60.6^{* \wedge}$ & 18.5 & 28.6 & 18.0 & $27.2^{*}$ & $27.9^{*}$ \\
\hline II & 48 & 19.3 & 26.6 & $12.8^{\wedge}$ & 18.8 & 29.4 & $10.4^{\wedge}$ & $39.9^{* \wedge}$ & $46.8^{* \wedge}$ \\
\hline III & 24 & $31.4^{\wedge}$ & $46.4^{*}$ & $50.0^{*}$ & $40.8^{*}$ & $44.3^{*}$ & $42.6^{*}$ & $47.1^{*}$ & $43.8^{*}$ \\
\hline III & 48 & 31.0 & 39.3 & 36.9 & $49.6^{* \wedge}$ & 39.7 & $23.6^{\wedge}$ & $53.6^{* \wedge}$ & $86.4^{* \wedge}$ \\
\hline Average & & 20.5 & 36.6 & 38.4 & 39.9 & 39.7 & 28.6 & 44.5 & 49.1 \\
\hline
\end{tabular}


$(2 \times 2$ contingency table, $p=0.0000$ and $p=0.0005$, respectively).

Larvae challenged with PMV 19 experienced an average mortality of approximately $40 \%$ (Table 3 ). These larval groups were significantly different from the unchallenged control larval groups in Expt III after 24 and $48 \mathrm{~h}(2 \times 2$ contingency table, $\mathrm{p}=0.0481$ and $\mathrm{p}=0.0003$, respectively). When compared to larval groups challenged with Vibrio pectenicida, significant differences in mortality were found in Expt I after $24 \mathrm{~h}$ $(2 \times 2$ contingency table, $p=0.0002)$ and Expt III after $48 \mathrm{~h}(2 \times 2$ contingency table, $\mathrm{p}=0.0370)$.

PCR verified that the randomly sampled bacteria taken after each counting ( 24 and $48 \mathrm{~h}$ ) and challenge experiment, were LT 06 and LT 13 that were used for challenge (Figs. $1 \& 2$ ). The use of specific primers against these 2 bacterial strains produced fragments similar in size to the fragment size produced by the primers LT 06 (417 bp) and LT 13 (405 bp). Some variations in the intensity of the fragments were detected.

\section{Immunohistochemistry}

Formaldehyde fixation produced contraction of the larvae prior to embedding, complicating the reading of slides and interpretation of immunohistochemical staining. The structure of larvae, before and after fixation, is shown in Fig. 3. Fig. 3c was drawn from Fig. 4, and represents an explanation of Figs. 4 to 13.

Cross-reactions among the 3 antisera, anti-A496, anti-LT 06 and anti-LT 13 were not found, either when tested directly on bacteria or on larval tissue samples. The unchallenged control larvae did not display positive immuno-staining when stained with anti-A496 and anti-LT 06 (Fig. 4). However, approximately $50 \%$ of the unchallenged control larvae displayed specific immuno-staining inside the stomach and digestive area and endothelial cells when stained with antiLT 13 serum (see Fig. 13). This staining was generally weaker than in larvae challenged with LT 13. The morphology of all control larvae was normal and displayed no signs of tissue damage (Fig. 4). The immunohistochemical examinations showed no relationship between pathogenesis and larval age.

Immuno-staining revealed large differences among the 3 larval groups; challenged control larval groups (larvae challenged with Vibrio pectenicida) and larval groups challenged with LT 06 or LT 13. Larvae challenged with $V$. pectenicida and LT 06 displayed similarities when immuno-stained (Figs. 5 \& 8) and showed similar signs of infection in comparison with larvae challenged with LT 13. In addition, most larvae were positively stained on the outer shell and mantle surfaces.

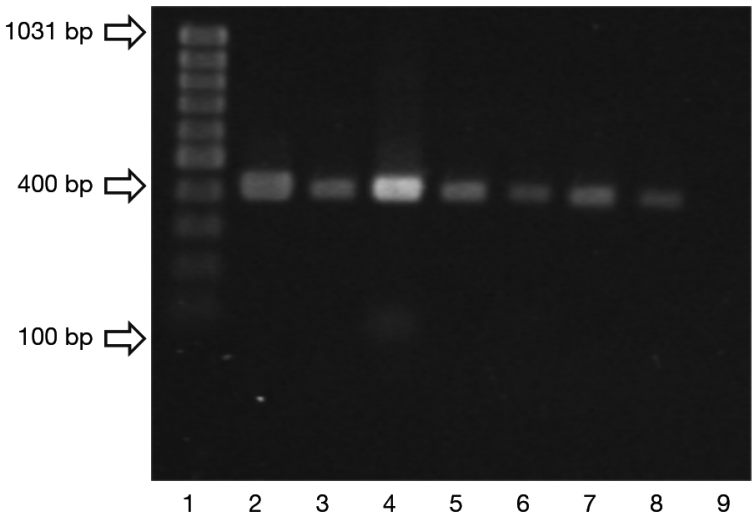

Fig. 1. Agarose gel electrophoresis photo of PCR-amplified $16 \mathrm{~S}$ rDNA in bacterial isolates sampled from the 24-well multidishes challenged with LT 06. Lanes 2 to 7 : bacterial isolates taken from the 24 -well mulitidishes from the different challenge experiments randomly sampled after each count; Lane 8: LT 06 used as positive control; Lane 9: Strain LT 13 used as negative control; Lane 1: standard marker. All templates are diluted 1:100

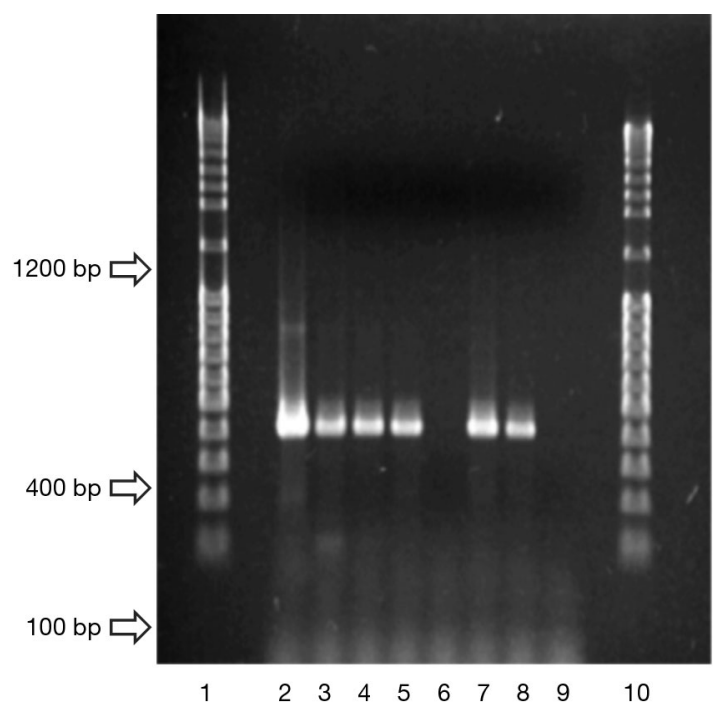

Fig. 2. Agarose gel electrophoresis photo of PCR amplified 16S rDNA in bacterial isolates sampled from the 24-well multidishes challenged with LT 13. Lanes 2 to 5: bacterial isolates taken from the 24-well multidishes from the different challenge experiments randomly sampled after each count; Lane 6: bacterial strain LT 06 used as negative control; Lanes 7 and 8: LT 13 used as positive control; Lane 9: core mix with no template; Lanes 1 and 10: standard markers. All templates are diluted 1:100

All challenged control larvae examined displayed positive immuno-staining. Infection was located in oesophagus, stomach and rectum, spreading in the areas around the digestive mass, especially the endothelial mucosa, and to the surrounding tissues. In most of the larvae, necrotic tissue and pycnotic cells could be observed (Figs. 5 \& 6). In challenge Expt III a 


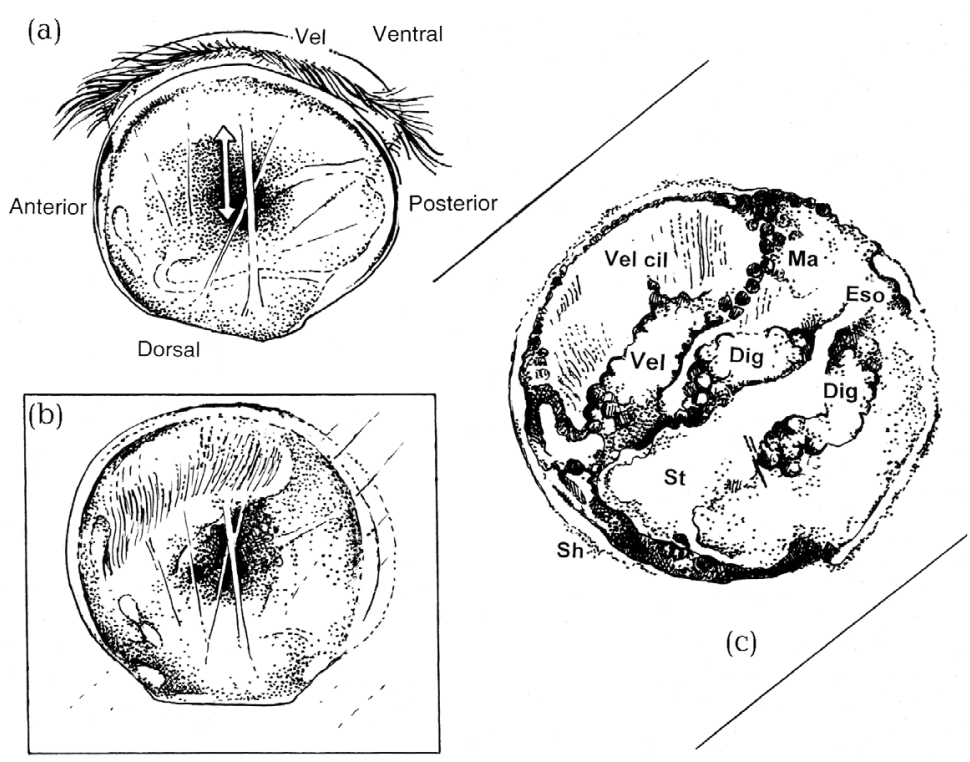

Fig. 3. Pecten maximus. Orientation and tissues seen in the sections (see Figs. 4-13). (a) illustrates the larva prior to fixation and how the velum contracts (arrows). (b) illustrates the larvae after fixation, with the contracted velum inside the thin shell, folded inwards with a longitudinal furrow and ciliar rim, underlying the mantle lobes. The longitudinal section that cuts through the approximate centre of the larva (indicates orientation of the larva section, cut to illustrate [c]), includes parts of stomach and gut. The ventral part includes parts of the contracted velum and mantle. (c) Tissues and body compartments of the larva corresponding to the larva shown in Fig. 4 (where strong staining covers the details and makes difficult any differentiation between the mantle cells, the thin epithelium of the velum roof and the larger cells of the velum basis). Lines indicate counter-clockwise turning, to the same orientation as Fig. 4. Eso: esophagus; St: stomach; Dig: digestive cells; Sh: shell matrix; Vel cil: velum cilia; Ma: mantle cells

clear difference was seen in the positive immunostaining between 24 and 48 h (Figs. 6 \& 7). All larvae challenged for $48 \mathrm{~h}$ were generally infected and appeared positively immuno-stained in most or all tissues (Fig. 7). This clear difference was not found in the 2 previous challenge experiments or in larval groups challenged with LT 06 and LT 13. Despite the positive intracellular immuno-staining of mucosal cells (Fig. 6, arrow), no positive identification of bacterial cells was confirmed in any of the individuals examined, either inside the digestive mass or intracellularly in epithelial cells.

In contrast to larvae challenged with Vibrio pectenicida, examination of larvae challenged with LT 06 revealed apparently intact bacterial cells inside the digestive mass and inside mucosal cells (Fig. 8, indicated with small arrow). Otherwise, the challenge results with LT 06 apparently had similar impact on the scallop larvae as $V$. pectenicida. Infection was basically located in the gut and the digestive area, although spread to the surrounding area in some larvae. Although a few larvae were generally infected, larvae challenged for $48 \mathrm{~h}$ did not appear to be more severely affected by the infection than larvae challenged for $24 \mathrm{~h}$. Despite challenge, 2 larvae, one in challenge Expt I (48 h) and one in challenge Expt III (48 h), displayed a total absence of specific immuno-staining (Fig. 9). Other larvae on the same sections, adjacent to these unstained larvae, were all positively stained (Fig. 10).

All the examined larvae examined from the challenge with LT 13 displayed positive immuno-staining. The infection was apparently less severe, as they were less positively stained than larvae challenged with Vibrio pectenicida and LT 06. Positive immuno-staining was limited to visual bacteria inside the digestive area and mucosal cells (Figs. 11 \& 12). Surrounding tissues were not infected and appeared normal. Intracellular bacteria could not be observed.

\section{DISCUSSION}

Scallop larva challenged with Vibrio pectenicida and the $V$. splendidus-like strain LT 06 showed many similarities regarding pathology, immuno-staining and mortality. Apparently our study is the first attempt to characterise such infections in bivalves by immunohistochemistry. This method enabled us to visualise affected tissue in the digestive mass and gut area of larvae challenged with these bacteria. Infection seemed to spread from these areas to the surrounding tissues. Together with the mortality results, these observations demonstrate that LT 06, like $V$. pectenicida, is pathogenic to scallop larvae. This supports the results of Nicolas et al. (1996) who described a strain resembling V. splendidus associated with mortality in scallop Pecten maximus larval cultures.

Immunohistochemical examinations of larval groups challenged with Vibrio pectenicida revealed no bacterial cells, despite a high degree of positive immunostaining. A general experience at our laboratory in studies of fish larvae with identical immuno-staining protocols ( $\varnothing$. Bergh unpubl.) is that tissue samples exposed to pathogenic Vibrio spp. will be positively stained in areas around the stained bacteria. This is probably due to staining of partially dissolved extracellular bacterial products. Lambert et al. (1998, 2001) 

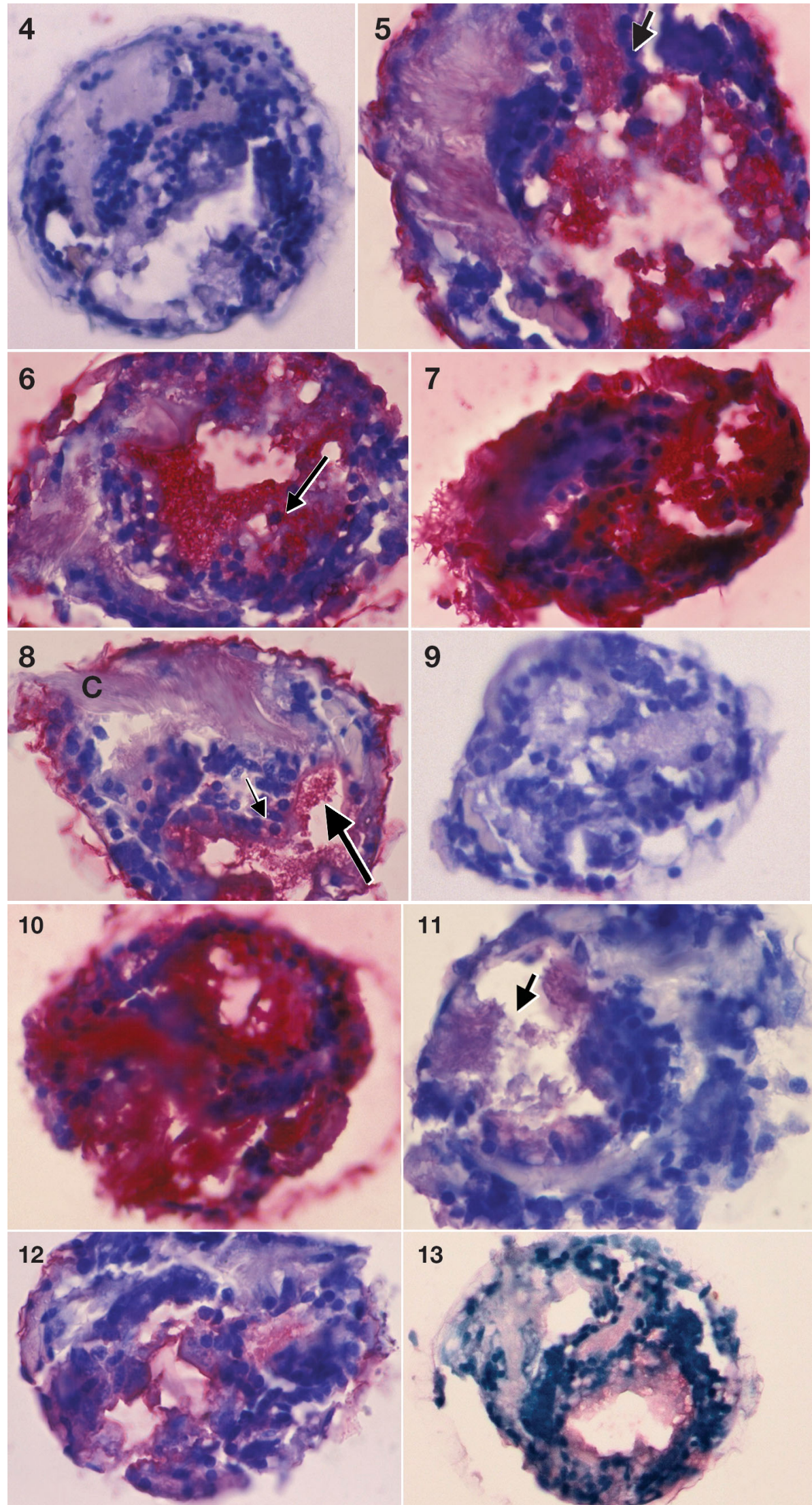
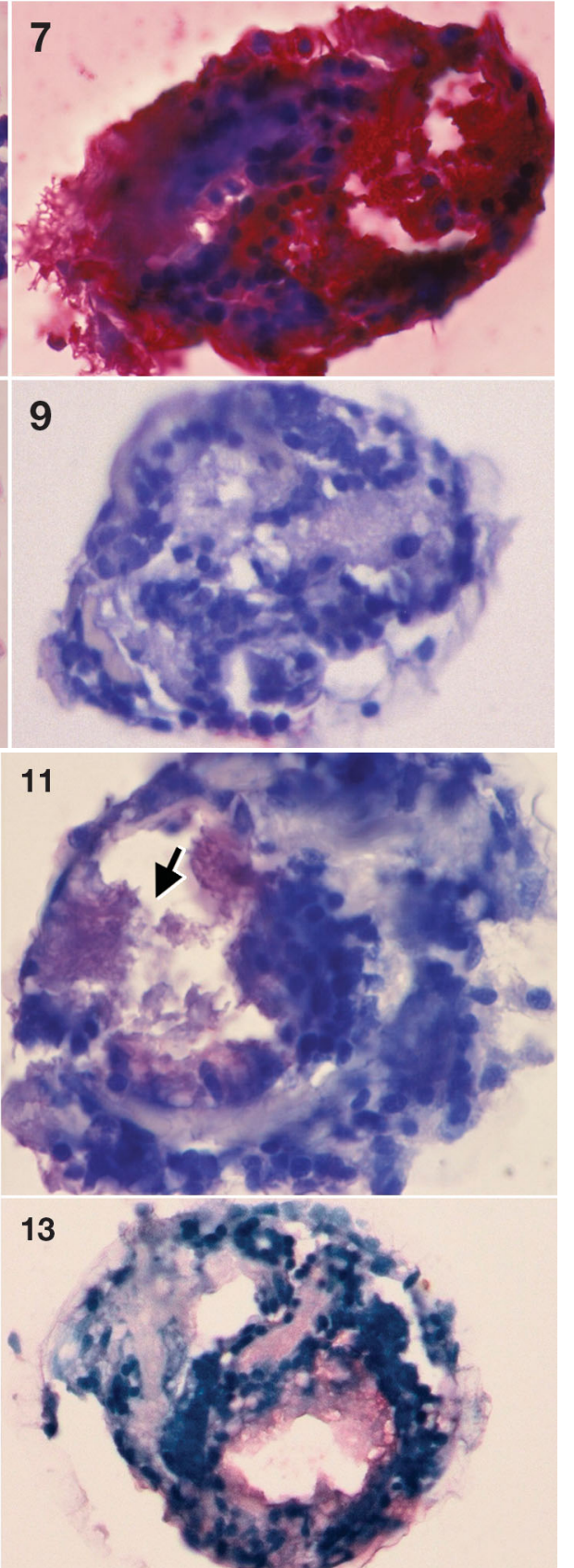

Figs. 4 to 13. Pecten maximus. Immunohistochemical staining of paraffin sections from larvae. Avidine-biotin-alkaline phosphatase method, rabbit anti-A496, -LT 06 and -LT 13 serum and Shandon haematoxylin counterstained. Positive immunohistochemistry is visualised by red colour. Counterstaining gives tissues different tones of blue. Larval diameters range between 90 and $150 \mu \mathrm{m}$. Fig. 4. Unchallenged, healthy larva stained with anti-LT 06. Figs. 5, $6 \&$ 7. Larva challenged with Vibrio pectenicida for $24 \mathrm{~h}$ (Fig. 6) and $48 \mathrm{~h}$ (Figs. 5 \& 7 ) stained with anti-A496. In Fig. 5 note intracellular staining in mucous cells (arrow). Red area inside digestive mass is probably a cluster of bacteria. Figs. $6 \& 7$ show variation in infectivity between 24 and $48 \mathrm{~h}$ observed in Expt III. In Fig. 6 the esophagus (arrow) and digestive areas, in particular, are clearly positively stained together with the shell surface. Fig. 7. Totally infected larvae $48 \mathrm{~h}$ post challenge. Figs. 8, $9 \& 10$. Larvae challenged with LT 06 for $48 \mathrm{~h}$, stained with anti LT 06. Fig. 8. Mantle surface, shell matrix and stomach wall are positively stained, and bacteria are visible and positively stained in the stomach (large arrow). Intracellular bacteria are verified in mucous cells (small arrow). The cilia (C) are also positively stained. Fig. 9. Note absence of immuno-staining in spite of bacterial exposure for $48 \mathrm{~h}$. Larvae show no signs of infection. Fig. 10. Larvae situated next to larvae in Fig. 8. Note the generally positive immuno-staining. Figs. 11 \& 12. Larvae challenged with LT 13 for 24 and $48 \mathrm{~h}$, respectively, stained with anti-LT 13. Fig. 11. Bacteria are seen in stomach and digestive area (arrow). Positive staining is restricted to digestive mass, showing no signs of infiltrating the surrounding area. Fig. 12. Positive immunostaining is seen on shell surface, on stomach wall and in esophagus. Fig. 13. Unchallenged control larvae stained with anti-LT 13. Positive immuno-staining is seen in esophagus, stomach lumen and endothelial cells 
demonstrated that $V$. pectenicida is highly toxic to Pecten maximus larvae due to an intracellular release of toxins that inhibit the respiratory burst activity of the haemocytes. These toxins may infiltrate the larval tissue. It is likely that polyclonal antiserum anti-A496 labelled some of these released toxins and possibly other compounds, and thereby positively stained the larval tissue, even though no bacterial cells were found. Verification of the presence of bacterial cells was difficult in all challenged larvae, partly due to clustering of bacterial cells. The large red area inside the digestive mass in some larvae (see Fig. 6) could be clusters of bacteria. The size of the scallop larvae (approximately 100 to $150 \mu \mathrm{m}$ ) and the low number of cells made observation of tissue degeneration and necrosis difficult. Most challenged larvae displayed positive immuno-staining on the shell surface and mantle. This could be due to bacterial adhesion to the surface of the larvae, but could also be due to lack of washing of the larvae prior to fixation.

Few papers describe scallop larval anatomy, and the majority are based on electron microscopy of veliger larvae (Cragg \& Crisp 1991). However these examinations have limited relevance to immunohistochemical examinations. The development of the immunohistochemical protocol described herein was optimised for the visualisation of the presence and modes of action of certain bacteria. However, the method is clearly suboptimal for purposes of precise morphological studies.

The challenge experiments showed that all challenged larval groups suffered higher average mortality than the unchallenged control groups. In comparison with the larval groups challenged with Vibrio pectenicida, all challenged groups, except those challenged with LT 13, experienced average higher mortality. From the mortality results, we consider that the bacterial strains PMV 18, PMV 19, LT 06, LT 21 and LT 73 are pathogenic to scallop larvae.

In contrast, larval groups challenged with LT 13 suffered relatively low average mortality and the immunohistochemical examinations revealed a lesser degree of infection compared with larvae challenged with Vibrio pectenicida and LT 06. However, Denaturating Gradient Gel Electrophoresis (DGGE) showed bacteria apparently identical to LT 13 to be frequently present in larval cultures suffering from high mortality (R. A. Sandaa unpubl.). Thus this bacterium may act as a secondary opportunistic pathogen that causes disease and mortality in already weakened larvae. Many other factors, such as broodstock condition, egg quality, larval condition and feed affect larval growth, development and survival in mussels (Phillips 2002) and scallops (Seguineau et al. 1996, 2001, Soudant et al. 1998).
Some of the unchallenged control larvae were positively stained with the antiserum anti-LT 13 in the digestive mass and gut area. Compared with larvae challenged with LT 13, this positive staining was weaker. Although neither bacterial samples nor larval tissue samples revealed cross-reaction, cross-reaction with other bacteria present inside the larval lumen is possible. The scallop larvae in our experiment were not axenic, and were not kept in a sterile environment prior to the challenge experiments. When specific primers for the bacterial strains LT 06 and LT 13 were used, no other bacteria present in the wells were detected. Recently, characterisations of bacterial flora associated with Pecten maximus larvae have been performed by DGGE of PCR-amplified 16S rDNA (Sandaa et al. 2003). This method provides an overview of the bacterial community, including both culturable and non-culturable components. Full sequencing of the 16S rDNA and Restriction Fragment Length Polymorphism (RFLP) for genotyping 16S rRNA are 2 methods for characterising unknown cultured bacteria. The latter was used by Jensen et al. (2002) to characterise bacteria cultured from halibut Hippoglossus hippoglossus fry. LT 13 has been isolated from the microalgae Chaetoceros calcitrans, which is used as feed for scallop larvae (Torkildsen et al. 2005). The bacterium could be inside the larvae as a consequence of feeding. Bacteria accumulating in the algal cultures may influence the bacterial flora associated with filterfeeders such as bivalve larvae. Skjermo \& Vadstein (1993) found that adding algae to the rearing water of halibut larvae increased the bacterial concentration by $45 \%$ and that the bacterial flora associated with fish larvae was related to the flora in the water. The DGGE profile of the bacterial community in a mixed algal culture resembled the DGGE profile of the algae present in the highest concentration (Sandaa et al. 2003). This suggests that additions of algae may influence the bacterial community. However, a clear difference in the DGGE profile of bacteria associated with the scallop larvae and the DGGE profile of the water samples was also found.

The bacterial strains PMV 18, PMV 19, LT 06, LT 21 and LT 73 all resemble Vibrio splendidus (Torkildsen et al. 2005). $V$. splendidus strains are widely spread in the marine ecosystem and cause disease in various aquatic organisms including the Pacific oyster (Lacoste et al. 2001, Waechter et al. 2002), great scallop (Nicolas et al. 1996), turbot Scophthalmus maximus larvae (Gatesoupe et al. 1999), gilt-head sea bream Sparus aurata (Balebona et al. 1998) and juvenile giant tiger shrimps Penaeus monodon (Leaño et al. 1998). The $V$. splendidus biovar II-related strain TNEMF6, caused a cumulative mortality of $80 \%$ in Pacific oyster spat (Waechter et al. 2002). V. splendidus infect a wide 
range of animals. Not all $V$. splendidus-related strains are pathogenic (Waechter et al. 2002). This could explain the differences in mortality among the strains used in this challenge experiment. The number of larvae inside the wells likely affected larval survival. Wells containing large amounts of larvae may provide better growth for the bacteria and an increased in infection rates.

Three of the bacterial suspensions were at a concentration of $10^{7}$ cells $\mathrm{ml}^{-1}$ instead of $10^{8}$ when they were added to the wells. In Expt II the concentration of bacteria in the suspension of Vibrio pectenicida was $4.0 \times$ $10^{7} \mathrm{CFU} \mathrm{ml} \mathrm{m}^{-1}$, and in Expts I and III the bacterial concentrations were $3.0 \times 10^{8}$ and $5.5 \times 10^{8} \mathrm{CFU} \mathrm{ml}^{-1}$, respectively. The low mortality in Expt II compared to the mortality in Expt I may have been related to the differences in cell concentration of the bacterial suspensions. However, concentration differences between the suspensions used in Expts II and III did not affect the mortality. Cell concentrations of the PMV 18 suspensions added in Expts I and III were $8.0 \times 10^{7}$ and $5.0 \times 10^{7} \mathrm{CFU} \mathrm{ml}{ }^{-1}$, respectively. In Expt II the concentration was $2.0 \times 10^{8} \mathrm{CFU} \mathrm{m}^{-1}$. PMV 18 caused similar mortality rates in all 3 challenge experiments. Thus it cannot be concluded if differences in bacterial concentrations may have affected larval mortality. In a similar multidish challenge experiment with Tenacibaculum ovolyticum (previously Flexibacter ovolyticus), V. anguillarum and Aeromonas salmonicida subsp. salmonicida, on eggs and larvae of Atlantic halibut Hippoglossus hippoglossus and Atlantic cod Gadus morhua, mortality increased with increasing challenge dose (Bergh 2000).

In conclusion, immunohistochemistry can be a powerful tool for studies of diseases of larval bivalves. Our results indicate that the Vibrio splendidus-like strains tested are pathogenic to scallop larvae. The pathology resembles infections with $V$. pectenicida. The Pseudoalteromonas-like strain LT13 is probably not a primary pathogen, but could act as a secondary opportunistic bacterium.

Acknowledgements. This study was financially supported by the Research Council of Norway; grant no.: 144121/130. We thank Ingrid Uglenes and Heidi Kongshaug for technical assistance, and Scalpro AS for supplying the larvae.

\section{LITERATURE CITED}

Allam B, Paillard C, Ford SE (2002) Pathogenicity of Vibrio tapetis, the etiological agent of brown ring disease in clams. Dis Aquat Org 48:221-231

Balebona MC, Zorrilla T, Moriñigo MA, Borrego JJ (1998) Survey of bacterial pathologies affecting farmed gilt-head sea bream (Sparus auratus L.) in southwestern Spain from 1990 to 1996 . Aquaculture 166:19-35
Bergh Ø (2000) Bacterial pathogens associated with early life stages of marine fish. In: Bell CR, Brylinsky M, JohnsonGreen P (eds) Microbial biosystems: new frontiers. Proceedings of the 8th International Symposium on Microbial Ecology, Atlantic Canada Society for Microbial Ecology, Halifax, p 221-228

Bergh $\varnothing$, Strand $\varnothing$ (2001) Great scallop, Pecten maximus, research and culture strategies in Norway: a review. Aquacult Int 9:305-318

Birkbeck TH, McHenery JG (1982) Degradation of bacteria by Mytilus edulis. Mar Biol 72:7-15

Borrego JJ, Castro D, Luque A, Paillard C, Maes P, Garcia MT, Ventosa A (1996) Vibrio tapetis sp. nov., the causative agent of the brown ring disease affecting cultured clams. Int J Syst Bacteriol 46(2):480-484

Cragg SM, Crisp DJ (1991) The biology of scallop larvae. In: Shumway SE (ed) Developments in aquaculture and fish science, Vol. 21. Scallops: biology, ecology and aquaculture. Elsevier, Amsterdam, p 75-132

Crosby MP, Newell RIE, Langdon CJ (1990) Bacterial mediation in the utilization of carbon and nitrogen from detrital complexes by Crassostrea virginica. Limnol Oceanogr 35(3):625-639

Douillet P (1993a) Bacterivory in Pacific oyster Crassostrea gigas larvae. Mar Ecol Prog Ser 98:123-134

Douillet P (1993b) Carbon contribution through bacterivory in larvae of the Pacific oyster Crassostrea gigas. Mar Ecol Prog Ser 102:303-314

Douillet P, Langdon CJ (1993) Effects of marine bacteria on the culture of axenic oyster Crassostrea gigas (Thunberg) larvae. Biol Bull 184:36-51

Douillet PA, Langdon CJ (1994) Use of a probiotic for the culture of larvae of the Pacific oyster (Crassostrea gigas Thunberg). Aquaculture 119:25-40

Elston R (1986) Occurrence of branchial rickettsiales-like infections in two bivalve molluscs, Tapes japonica and Patinopecten yessoensis, with comments on their significance. J Fish Dis 9:69-71

Gatesoupe FJ, Lambert C, Nicolas JL (1999) Pathogenicity of Vibrio splendidus strains associated with turbot larvae, Scophthalmus maximus. J Appl Microbiol 87:757-763

Gruffydd LLD, Beaumont AR (1970) Determination of the optimum concentration of eggs and spermatozoa for the production of normal larvae in Pecten maximus (Mollusca Lamellibranchia). Helgol Wiss Meeresunters 20:486- 497

Hine PM, Diggles BK (2002) Prokaryote infections in the New Zealand scallops Pecten novaezelandiae and Chlamys delicatula. Dis Aquat Org 50:137-144

Hovgaard P, Mortensen S, Strand Ø (2001) Skjell: biologi og dyrking. Kystnæringens Forlag og Bokklubb AS, Bergen, p 18-92 (in Norwegian)

Jensen S, Bergh Ø, Enger $\varnothing$, Hjeltnes B (2002) Use of PCRRFLP for genotyping 16S rRNA and characterizing bacteria cultured from halibut fry. Can J Microbiol 48:379-386

Knappskog DH, Rødseth OM, Slinde E, Endresen C (1993) Immunochemical analyses of Vibrio anguillarum strains isolated from cod, Gadus morhua L., suffering from vibriosis. J Fish Dis 16:327-338

Lacoste A, Jalabert F, Malham S, Cueff A, Gélébart F, Cordevant C, Lange M, Poulet SA (2001) A Vibrio splendidus strain is associated with summer mortality of juvenile oysters Crassostrea gigas in the Bay of Morlaix (North Brittany, France). Dis Aquat Org 46:139-145

Lambert C, Nicolas JL, Cilia V, Corre S (1998) Vibrio pectenicida sp. nov., a pathogen of scallop (Pecten maximus) larvae. Int J Syst Bacteriol 48:481-487

Lambert C, Nicolas JL, Bultel V (2001) Toxicity to bivalve 
hemocytes of pathogenic Vibrio cytoplasmic extract. J Invertebr Pathol 77:165-172

Leaño EM, Lavilla-Pitogo CR, Paner MG (1998) Bacterial flora in the hepatopancreas of pond-reared Penaeus monodon juveniles with luminous vibriosis. Aquaculture 164:367- 374

Le Gall G, Chagot D, Mialhe E, Grizel H (1988) Branchial Rickettsiales-like infection associated with a mass mortality of the sea scallop Pecten maximus. Dis Aquat Org 4: 229-232

Le Gall G, Mialhe E, Chagot D, Grizel H (1991) Epizootiological study of rickettsiosis of the Saint-Jacques scallop Pecten maximus. Dis Aquat Org 10:139-145

Leibovitz L (1989) Chlamydiosis: a newly reported serious disease of larval and postmetamorphic bay scallop, Argopecten irradians (Lamarck). J Fish Dis 12:125-136

Le Roux F, Gay M, Lambert C, Waechter M, Poubalanne S, Chollet B, Nicolas JL, Berthe F (2002) Comparative analysis of Vibrio splendidus-related strains isolated during Crassostrea gigas mortality events. Aquat Living Resour 15:251-258

Morrison C, Shum G (1982) Chlamydia-like organisms in the digestive diverticula of the bay scallop, Argopecten irradians (Lmk). J Fish Dis 5:173-184

Nicolas JL, Corre S, Gauthier G, Robert R, Ansquer D (1996) Bacterial problems associated with scallop Pecten maximus larval culture. Dis Aquat Org 27:67-76

Oeding P (1957) Agglutinability of pyrogenic Staphylococci at various conditions. Acta Pathol Microbiol Scand 41: $310-324$

Phillips NE (2002) Effects of nutrition-mediated larval condition on juvenile performance in a marine mussel. Ecology 83(9):2562-2574

Renault T, Cochennec N (1995) Chlamydia-like organisms in ctenidia and mantle cells of the Japanese oyster Crassostrea gigas from the French Atlantic coast. Dis Aquat Org 23:153-159

Riquelme C, Hayashida G, Toranzo AE, Vilches J, Chavez P (1995) Pathogenicity studies on a Vibrio anguillarumrelated (VAR) strain causing an epizootic in Argopecten purpuratus larvae cultured in Chile. Dis Aquat Org 22: 135-141

Riquelme C, Toranzo AE, Barja JL, Vergara N, Araya R (1996a) Association of Aeromonas hydrophila and Vibrio alginolyticus with larval mortalities of scallop (Argopecten purpuratus). J Invertebr Pathol 67:213-218

Riquelme C, Hayashida G, Araya R, Uchida A, Satomi M, Ishida Y (1996b) Isolation of a native bacterial strain from the scallop Argopecten purpuratus with inhibitory effects against pathogenic Vibrios. J Shellfish Res 15(2):369-374

Riquelme C, Araya R, Vergara N, Rojas A, Guaita M, Candia M (1997) Potential probiotic strains in the culture of the Chilean scallop Argopecten purpuratus (Lamarck 1819). Aquaculture 154:17-26

Riquelme CE, Jorquera MA, Rojas AI, Avendaño RE, Reyes N (2001) Addition of inhibitor-producing bacteria to mass cultures of Argopecten purpuratus larvae (Lamarck, 1819). Aquaculture 192:111-119

Robert R, Miner P, Nicolas JL (1996) Mortality control of scallop larvae in the hatchery. Aquacult Int 4:305-313

Editorial responsibility: Albert Sparks,

Seattle, Washington, USA
Ruiz-Ponte C, Samain JF, Sánchez JL, Nicolas JL (1999) The benefit of a Roseobacter species on the survival of scallop larvae. Mar Biotechnol 1:52-59

Samain JF, Cochard JC, Chevolot L, Daniel JY and 6 others (1987) Effet de la qualité de l'eau sur la croissance larvaire de Pecten maximus en écloserie: observations préliminaires. Haliotis 16:363-381

Sandaa RA, Magnesen T, Torkildsen L, Bergh Ø (2003) Characterisation of the bacterial community associated with early stages of great scallop (Pecten maximus), using Denaturing Gradient Gel Electrophoresis (DGGE). Syst Appl Microbiol 26:302-311

Seguineau C, Laschi-Loquerie A, Moal J, Samain JF (1996) Vitamin requirements in great scallop larvae. Aquacult Int $4: 315-324$

Seguineau C, Saout C, Paulet YM, Muzellec ML, Quéré C, Moal J, Samain JF (2001) Changes in tissue concentrations of the vitamins B1 and B2 during reproductive cycle of bivalves Part 1: The scallop Pecten maximus. Aquaculture 196:125-137

Skjermo J, Vadstein O (1993) The effect of microalgae on skin and gut bacterial flora of halibut larvae. In: Reinertsen $\mathrm{H}$, Dahle LA, Jørgensen L, Tvinnereim K (eds) Fish farming technology. Balkema, Rotterdam, p 61-67

Soudant P, Le Coz JR, Marty Y, Moal J, Robert R, Samain JF (1998) Incorporation of microalgae sterols by scallop Pecten maximus (L.) larvae. Comp Biochem Physiol 199A(2):451-457

Torkildsen L (2004) Mortalities in a hatchery of the great scallop Pecten maximus. PhD thesis, Department of Biology, University of Bergen

Torkildsen L, Magnesen T (2004) Hatchery production of scallop larvae (Pecten maximus) - survival in different rearing systems. Aquacult Int 12(4-5):489-507

Torkildsen L, Samuelsen OB, Lunestad BT, Bergh Ø (2000) Minimum inhibitory concentrations of chloramphenicol, florfenicol, trimethoprim/sulfadiazine and flumequine in seawater of bacteria associated with scallops (Pecten maximus) larvae. Aquaculture 185:1-12

Torkildsen L, Coyne R, Samuelsen OB, Magnesen T, Bergh Ø (2002) Treatment of the early life stages of scallop (Pecten maximus) with antimicrobial agents; searching for an alternative to chloramphenicol. Aquacult Int 10(5):399-409

Torkildsen L, Lambert C, Nylund A, Magnesen T, Bergh Ø (2006) Bacteria associated with early life stages of the great scallop, Pecten maximus: impact on larval survival. Aquacult Int (in press)

Waechter M, Le Roux F, Nicolas JL, Marissal É, Berthe F (2002) Caractérisation debactéries pathogènes de naissain d'huitre creuse Crassostrea gigas. C R Biol 325: 231-238

Walpole RE, Myers RH, Myers SL, Ye K (2002) Testing for several proportions. Probability and statistics for engineers and scientists, 7 th edn. Pearson Education International, Prentice Hall, NJ, p 340-342

Wu X, Pan J (1999) Studies on Rickettsia-like organism disease of the tropical marine pearl oyster. I: The fine structure and morphogenesis of Pinctada maxima pathogen Rickettsia-like organism. J Invertebr Pathol 73: 162-172

Submitted: January 6, 2005; Accepted: November 2, 2005

Proofs received from author(s): March 15, 2006 